Working Paper Series of the Centre for Advanced Studies "Multiple Secularities Beyond the West, Beyond Modernities"

\#7: Markus Dreßler. "Modes of Religionization: A Constructivist Approach to Secularity" Leipzig, February 2019

(C) Markus Dreßler, 2019

This working paper has been published online and can be downloaded from www.multiple-secularities.de/publications/working-papers or ordered in print via email to multiple-secularities@uni-leipzig.de

The HCAS's Working Paper Series serves to disseminate the research results of work in progress prior to publication to encourage the exchange of ideas and academic debate. Inclusion of a paper in the Working Paper Series should not limit publication in any other venue. Copyright remains with the authors.

Please cite as:

Dreßler, Markus. "Modes of Religionization: A Constructivist Approach to Secularity" Working Paper Series of the HCAS "Multiple Secularities - Beyond the West, Beyond Modernities" 7, Leipzig, February 2019.

Leipzig University

HCAS "Multiple Secularities - Beyond the West, Beyond Modernities"

Nikolaistraße 8-10

04109 Leipzig

Germany

The HCAS is part of Leipzig University and funded by the German Research Foundation (DFG). 
Markus Dreßler

\section{Modes of Religionization}

A Constructivist Approach to Secularity 



\section{Modes of Religionization A Constructivist Approach to Secularity ${ }^{1}$}

\section{Introduction}

This article discusses four concepts: religionization, religio-secularization, religio-secularism, and religion-making. These concepts are proposed as heuristic devices for the analysis of the processes through which social networks, practices, and discourses come to be understood as 'religious' or 'religion.'

I use the term 'religionization' to describe situations where assemblages of knowledge (structures, practices, discourses) are being made sense of through the modern concept of religion. I use 'religio-secularization' to illustrate the connection between religionization and secularization in the modern context. I use 'religio-secularism' to denote the knowledge regime that legitimizes processes of religionization and secularization. Finally, the term 'religion-making' is proposed as a means of focusing on agency in processes of religionization.

This article is based on the premise that processes of religionization and practices of religion-making have been intertwined with processes of secularization and politics of secularism. If we take a constructivist approach to religion, we must consider how to position secularity, conceived in terms of conceptual distinctions and structural differentiations, ${ }^{2}$ within this dynamic. This article suggests that, at least for the modern context, secularity can be regarded as a product of processes of religio-secularization and practices of

1 For the valuable comments on a previous draft of this text, I am indebted to Bjørn Ola Tafjord as well as members of the Multiple Secularities project, namely Hubert Seiwert, Monika Wohlrab-Sahr, Sana Chavoshian, Nader Sohrabi, Mohammed Magout, Lena Dreier and Kathrin Killinger.

2 As developed in the Multiple Secularities: Beyond the West, Beyond Modernities research project. See Kleine and Wohlrab-Sahr, "Research programme;" for an earlier exploration on multiple secularities within a modern framework, see Wohlrab-Sahr and Burchardt, "Multiple secularities." 
religion-making in which a religio-secular episteme was established. As with the Multiple Secularities approach, the constructivist approach to religion advanced here is interested in the historical conditions under which certain assemblages of knowledge and structures that are being related to religion and secularity are evidenced and gain leverage.

\section{Religionization and Multiple Secularities}

Religionization is proposed as a heuristic term that highlights practices through which religion is homogenized and reified. The term emphasizes the processes through which certain assemblages of knowledge, expressed in discourses and practices, are densified and become recognizable as 'religion.' While such processes are easily recognizable in the modern period, they are not restricted to it. ${ }^{3}$

Religionization is the subject of a growing body of academic literature - though not all scholars employ the term. This literature often follows in the footsteps of William Cantwell Smith, who in his seminal The Meaning and End of Religion established a critical approach to the reification of the concept of 'religion.' ${ }^{4}$ More recently, Talal Asad's Genealogies of Religion provided a detailed critique of the genealogy and politics of modern religion discourse. ${ }^{5}$ Asad investigated the discourses and practices through which religion was first bounded and reified in the modern West. In Formations of the Secular, he continued his genealogical inquiry, focusing on religion's modern binary other, the secular. ${ }^{6} \mathrm{He}$ aspired "to problematize 'the religious' and 'the secular' as clear-cut categories but also to search for the conditions in which they were clear-cut and were sustained as such." "I wanted to ask," he explains, "what are the conditions in which these dichotomies, these binaries, do seem to make sense?"'

One can draw a parallel between Asad's consideration of the conditions in which the religion-secular binary appears to make sense and the "reference problems" (a term borrowed from Niklas Luhmann) for secu-

3 See, for example, the differentiation of Christianity as religion from Judaism as discussed by Boyarin, Dying for God and Boyarin, Border lines. For the formation of Islam as a religion in late antiquity in relation to Christianity and Judaism see Hoyland, The late antique world of early Islam; cf. Schulze, Der Koran.

4 Smith, The meaning and end of religion, originally published in 1962.

5 Asad, Genealogies of religion.

6 Asad, Formations of the secular.

7 Asad, “Responses," 298. 
larity, which Monika Wohlrab-Sahr and Marian Burchardt formulated in their initial framing of a Multiple Secularities research project. ${ }^{8}$ WohlrabSahr and Burchardt define "multiple secularities" as

the forms of distinction between the religious and other social domains (which are thereby marked as non-religious) that are institutionalized and in part legitimized through guiding ideas. ${ }^{9}$

"Reference problems" are specific historical situations and societal circumstances that prompt secularity in terms of a cognitive separation between two spheres, as well as a cultural commitment ("guiding ideas") to maintaining this distinction. Wohlrab-Sahr and Burchardt suggest four ideal-typical reference problems for secularity:

(1) the problem of individual freedom vis-à-vis dominant social units [...]; (2) the problem of religious heterogeneity and the resulting potential or actual conflictuality; (3) the problem of social or national integration and development; and (4) the problem of the independent development of institutional domains. ${ }^{10}$

These reference problems, established within a differentiationist framework, are based on analysis of the modern condition and conceive of the political as constituted in a post-Enlightenment context. Similarly, Asad's concern with the conditions under which binary distinctions "do seem to make sense" indicates the importance of taking context into consideration when analyzing how 'religion' is being evidenced in the modern period. However, in contrast to the Multiple Secularities project, which conceives of distinctions as reflections of and tied into the social structures and historical reference problems to which they respond, Asadian critique inquires primarily into the epistemic forces through which the evidence of the secular - taken for granted by the Multiple Secularities perspective - is established. I would like to suggest that a social constructivist position that recognizes the social reality of distinctions and differentiation with regard to religion, while at the same time being interested in how this reality is being established, thus acknowledging its contingency, provides an opening

8 Wohlrab-Sahr and Burchardt, "Multiple secularities," 881.

9 Ibid., 886-87.

10 Ibid., 887. 
for establishing a dialogue between the Multiple Secularities perspective and Asadian genealogy.

Resonating both with the genealogical method and with the Multiple Secularities focus on conceptual distinctions, and structural and institutional differentiations related to such distinctions, I conceive of religionization in the modern context in a constructivist manner as "the signification of certain spaces, practices, narratives, and languages as religious (as opposed to things marked as secular)." ${ }^{11}$ Recognizing that religionization is inherently related to processes of secularization and politics of secularism, I suggest the term religio-secularization to capture and emphasize this interrelation. ${ }^{12}$ In the following section, I will explore changes in the concepts of din (Arab. din) and millet (Arab. milla) in late Ottoman-Turkish lexicographic discourse to illustrate the parallels between religionization and secularization and their semantic interrelation.

\section{Religio-Secularization}

In the first modern Ottoman dictionaries (Turkish-Turkish), published around the middle of the $19^{\text {th }}$ century, the term din was still anchored in the semantics of the classical Arabic lexicographic tradition. Within this tradition, the Quranic meanings of the term were dominant, although preIslamic meanings were retained due to the scrupulousness and idiosyncrasies of classical Arabic lexicographers. ${ }^{13}$ An example is the entry for din in the Ottoman dictionary of Mehmed Şevket Efendi (1804-1867), a member of the Mevlevi Sufi order who worked as a high-ranking bookkeeper in the Ottoman administration during the Tanzimat reform period. His dictionary, the Eser-i Şevket, was published in 1851 in Istanbul. Its entry for din lists more than twenty different meanings, the majority of which are Islamic in the sense that they consist of Quranic terms that appear in

11 Dressler, "Religio-secular metamorphoses," 281; see also Dressler, Writing religion, 65-66.

12 Writing about U.S. society, Martin E. Marty was probably the first to use the term "religio-secular" to denote a messiness of life that could not be grasped with the religion/secular binary. He argued that this polarizing binary did not "adequately express the ways that individuals, groups, and societies actually behave; most people blur, mesh, meld, and muddle together elements of both the secular and the religious, the worldly and the otherworldly, etc." (Marty, "Our religio-secular world," 42).

13 Glei and Reichmuth, "Religion between Last Judgment." 
the sacred text within the semantic field of $d i n .{ }^{14}$ These Quranic terms are interspersed with non-Quranic terms, some of which can clearly be related to Islam, ${ }^{15}$ whereas others are difficult to relate to it. ${ }^{16}$ Whereas the Eser-i Sevket still closely followed Arabic lexicographic examples, ${ }^{17}$ later Ottoman dictionaries would quickly drop their loyalty to this tradition, paving the way for a gradual homogenization of the semantic range of din with an ever greater adjustment towards an implicit concept of (world-)religion. The details of how late Ottoman notions of din changed - a process that in hindsight seems to have had a clear direction - still need to be established. This gradual development toward a general definition of religion in line with Western models reached its climax with the lemma din in the Yeni Türkçe Luğat ("New Turkish Dictionary") by Mehmet Bahaettin [Toven], first published in 1924: "Belief, veneration, loving affection, worship and obedience toward a creator of the entire world; actions, ethics, and feelings emerging from that creed." ${ }^{18}$

During the same period that the concept of din was religionized, other terms underwent a process of secularization in the sense of being stripped of their religious meanings and being re-organized according to a merely secular logic. The transformation of the term millet in late Ottoman lexicographic discourse is one example of this development. In the classical Arabic lexicographic tradition, the term milla is firmly embedded in Islamic semantics. This initially went unchallenged in Ottoman lexicographic discourse. Like other dictionaries of the period, the Eser-i S evket lists two meanings of millet: şeriat/sharia and din. ${ }^{19}$ Other sources which state that millet means şeriat or din often distinguish the former term as

14 Such as ceza/punishment, yawm ül-ceza/judgement day, İslam, adet/custom, taat/obedience, hesap/reckoning, sultan/strength, mülk/possession, hükm/ judgement, siret/path, millet/religion (Mehmed Şevket, Eser-i Şevket, 287). Here and throughout I use modern Turkish spelling for Ottoman terms and Arabic transliteration for Arabic terms where they are used in general contexts rather than those specific to the Ottoman Empire or Turkey.

15 Such as tedbir/disciplining, tevhid/oneness, galebe/victory, şeriat/sharia, takwa/ fear of God, masiyet/sin, hizmet/service, ihsan/benevolence, aziz olmak/being saintly, zelil olmak/being humbled (ibid.).

16 Such as daimi yağan yağmur/everlasting rain and maraz/disease (ibid.).

17 Mehmed Şevket Efendi explicitly acknowledges that he drew on the dictionary Qāmūs al-muhit (between 1405 and 1410) by Fīrūzābādì (d. 1414), which was translated into Turkish between 1814 and 1817 and published by Mütercim Âsım Efendi (1755-1819) as el-Okyânûsu'l-Basit.

18 Toven, Yeni Türkçe luğat, 149.

19 Mehmed Şevket, Eser-i Şevket, 637. 
having a certain emphasis on religion as a social entity. ${ }^{20}$ From the second half of the $19^{\text {th }}$ century, however, at the same time as din underwent a process of religionization, the term millet underwent a process of secularization. It lost its religious connotations and was gradually connected to the Western concept of 'nation. By the 1920s, in the early years of the Turkish Republic, this process was completed. The entry millet in the Yeni Türkçe Luğat reads as follows: "A group of people living on the same territory with common origin and language." ${ }^{21}$

I propose that the described conceptual transformations of the terms din and millet in late Ottoman lexicographic discourse can be conceived of as religio-secularization. The concept of millet was secularized, losing its traditional Islamic connotations, and acquiring instead a meaning congruent to the Western term 'nation.' Concomitantly, the concept of din was religionized in the sense of being recast in the language of the (world-)religion discourse. ${ }^{22}$ This, by extension, also meant a religionization of Islam in the sense that the din of Islam, religionized as it was, was increasingly regarded as its center. Consequently, the worldly aspects of the Islamic tradition (especially concerning the realms of economy and politics) were relegated to the periphery of the newly reified essentially Islamic. Aziz al-Azmeh has written about the "Islamization of Islam" as a modern practice in which both Western commentators as well as Muslims participated. ${ }^{23}$ Al-Azmeh saw this development as a product of an intense culturalism, a subjectification of various cultural units that was especially widespread in Europe, leading to a neglect of the historical rootedness of social and cultural phenomena. ${ }^{24}$ What Al-Azmeh describes relates to the reification of Islam already noted by W. C. Smith. ${ }^{25}$ Ultimately, few would argue that Islam is not a religion, but the question is whether Islam as a historical phenomenon should best be approached with a modern concept of religion that entails the secular as its generic other. If we approach Islam through a modern concept of religion that demands a secular outside of religion, we inevitably create a number of conceptual issues, the discussion of which goes beyond the scope of this article. ${ }^{26}$

20 Izutsu, God and man, 248-51.

21 Toven, Yeni Türkçe luğat, 483.

22 Masuzawa, Invention of world religions.

23 Al-Azmeh, Die Islamisierung des Islam, 7; the notion has been taken up in Bauer, Kultur der Ambiguität, chap. 6.

24 Al-Azmeh, Die Islamisierung des Islam, 8-12.

25 Smith, The meaning and end of religion; see also Tayob, Religion in modern Islamic discourse.

26 Dressler, Wohlrab-Sahr, and Salvatore, "Islamicate secularities." 


\section{Religio-Secularism}

I propose the term 'religio-secularism' to denote the knowledge regime that legitimizes processes of religio-secularization and strives for the normalization of such processes. For the modern period, we can

use the notion of "religio-secularism" to put emphasis on the manner in which the concepts of religion and the secular have been intertwined, forming a semantic continuum constituted by the oppositional way in which they are pointing to each other without being able to be defined independently from one another. It also points to how secularism and religionism are corresponding worldviews and practices. ${ }^{27}$

A good example of religio-secularism is the intervention by the Egyptian scholar 'Alì 'Abd al-Razị (1888-1966), "the first Muslim secularist." ${ }^{28}$ The controversial scholar, a teacher at the renowned Al-Azhar University, and a Muslim judge, argued that there was a clear separation in Islam between prophetic and sultanic (or kingly) leadership and government:

While the former is religion, the latter is the world. The former is divine, the latter is human. The former is a religious leadership, the latter a political one-and there is much distance between politics and religion. ${ }^{29}$

Al-Raziq's argument clearly shows how secularism presupposes a concept of religion that semantically depends on its juxtaposition to the secular. Al-Razīq presented this assessment in a short booklet ${ }^{30}$ published shortly after the abolition of the Caliphate in 1924. It thus needs to be read as an intervention into the pressing problem of the legitimation of government after the Caliphate.

In the modern period, the problem of the legitimation of government, compounded by the centralizing state's increasing powers, and the negotiation of the place and role of religion that this legitimation engenders, may be seen as a further reference problem for secularity. It highlights the

27 Dressler, "Beyond religio-secularism;" see also Jansen, "Beyond comparing secularisms."

28 Gazi, "The first Muslim secularist."

29 Al-Raziq, "Message not government," 31.

30 Al-Raziq, Al-Islām wa Ușūl al-Hukm. 
question of the political in the modern condition, which may "be regarded as the vantage point through which this antagonism/binary [of religion and the secular] is constantly reinforced." ${ }^{31}$ Furthermore, it points to the mutually constitutive impact of religion (defined vis-a-vis the political) and secularity (constituting itself vis-a-vis religion), and, more broadly, to the processes through which the religious/secular and similar binaries (such as religion/culture) are evidenced as means of describing, making sense of, and thus ordering the human experience as well as social formations in the modern world. One side effect of the described dynamic of religio-secularism is that, to the extent that we (contemporary students of the study of religion) are often confined to a positionality which is based on a modern and Western knowledge formation,

it has become almost impossible for us to rethink religion in nonpolitical ways. What I mean by "nonpolitical," simply, is an intellectual space that makes it possible to conceive of religion in a manner that does not necessarily implicate the political directly as a point of reference against which the domain of religion is demarcated. ${ }^{32}$

\section{Religion-Making}

From a social constructivist perspective, we can understand 'religion,' 'the secular', and their respective derivatives as social realities that are not a given, but are the product of continuous negotiation and objectification. This implies that we need to focus on agency in processes of religio-secularization and the specific locations in which religion, the secular, and so forth are produced, bounded, and distinguished against the background of particular contexts. ${ }^{33}$

The term 'religion-making' aims to shed light on the multiple layers of agency in religionization processes. A distinction between three major dimensions of religion-making - from above, from below, and from a pretended outside - has been proposed for that purpose. ${ }^{34}$ These dimensions

31 Dressler, "Beyond religio-secularism."

32 Ibid.

33 Beyer, "Conceptions of religion;" Dressler, "The social construction."

34 Mandair and Dressler, "Introduction," 21-22. For a comparable tripartite distinction, namely between theological, scientific, and official conceptions of religion, which focuses more on the trajectory of the formation of religion as a concept, see Beyer, "Conceptions of religion." The distinction between governed religion, expert religion, and lived religion that has been offered more re- 
reflect different ensembles of actors with different interests, and different positions of power, all of which are involved in politics of religionization and may form powerful symbioses. ${ }^{35}$

'Religion-making from above' can be defined as "a strategy from a position of power, where religion becomes an instrument of governmentality, a means to legitimize certain politics and positions of power." ${ }^{36}$ The notion refers to

authoritative discourses and practices that define and confine things (symbols, languages, practices) as "religious" and "secular" through the disciplining means of the modern state and its institutions (such as law-making, the judiciary, state bureaucracies, state media, and the public education system). ${ }^{37}$

What needs to be added is a reference to international institutions with legal and political authority, which are also important agents of religionmaking. ${ }^{38}$ Trevor Stack has argued that "religious-secular distinctions have been crucial to the way in which modern governments have rationalised their governance and marked out their sovereignty." ${ }^{39}$ The double perspective articulated by Stack is important: distinctions between the religious and the secular are employed as a mode of governance, and as a way of legitimizing claims to political sovereignty. ${ }^{40}$ Connecting religion-making politics to secularity, understood as a product of politics of distinction, Stark's assertion is very much in line with the notion of religion-making from above. It

cently by Elizabeth Shakman Hurd in her discussion of the politics of religious freedom follows a roughly parallel logic of differentiation between various arenas in which religion is being constructed (Hurd, Beyond religious freedom).

35 The chapters in Dressler and Mandair (Secularism and religion-making) offer empirically rich and theoretically engaged perspectives on various modes of religion-making and how they interrelate.

36 Mandair and Dressler, "Introduction," 21.

37 Ibid., 21-22. For an important collection addressing the dimension of religionmaking from above with a focus on law, see Sullivan, Yelle, and Taussig-Rubbo, After secular law; for further instructive studies focusing on law as an important instrument of religionization, see Hurd, "Alevis under law" and Telle, "Faith on trial," which focus on Turkey and Indonesia, respectively.

38 Hurd, Beyond religious freedom.

39 Stack, "Introduction," 1.

40 Ibid., 3. 
also connects the top-down mode of religion-making with the reference problem of the legitimation of government discussed above.

'Religion-making from below' can be defined as

\begin{abstract}
politics where particular social groups in a subordinate position draw on a religionist discourse to re-establish their identities as legitimate social formations distinguishable from other social formations through tropes of religious difference and/or claims for certain rights. ${ }^{41}$
\end{abstract}

It is important to understand that discourses can only establish their dominance through subordination of other discourses. ${ }^{42}$ Whether in appropriating or in subverting terms, religion-making from below therefore needs to be analyzed in relation to religion-making from above. The language of religion employed by particular groups for their particular purposes is an expression of particular stakes and interests, responding to particular contexts, traditions, and the struggle over their interpretation ('politics of doxa'). The notion of religion-making from below aims to acknowledge and underline that those who are in a subordinate position, such as groups that draw on the language of religion as a means to improve their particular social positions, may have considerable agency in religionization politics. Investigating the potentials and constraints of this agency should be one of the aims of our inquiry into the processes of the making of religion as well as the secular.

Scholarly work within the religio-secular field needs to reflect on its own position and "the siding effects of academic work." 33 Such work can easily become a tool for the vindication of particular political positions, both with regard to the justification and normalization of notions of 'orthodoxy', as well as with regard to narratives of victimization. This brings us to 'religion-making from a pretended outside, identified as

scholarly discourses on religion that provide legitimacy to the first two processes [of religion-making, from above and from below, by systematizing and thus normalizing the religious/secular binary. ${ }^{44}$

41 Mandair and Dressler, "Introduction," 21.

42 Pierre Bourdieu's theory of the religious field provides a good model for describing the dynamics that mark the relationship of groups with different positions of power in shared discursive contexts (Bourdieu, "Genesis and structure").

43 Tafjord, "Scales, translations, and siding effects," 168.

44 Mandair and Dressler, "Introduction," 21. 
That the role of the academic study of religion is more complex than naïve imaginations of it as an impartial surveyor of given religious phenomena might suggest, and that it has itself often been implicated in the discursive reification of religion was commented on very early on in the above-mentioned study by W. C. Smith. ${ }^{45}$ Subsequent critical initiates of the discipline, such as J. Z. Smith, author of the famous phrase "religion is solely the creation of the scholar's study"46 (1988), inspired students of the following generation to focus in more detail on the role of scholars in the construction of religion. ${ }^{47}$ The 'religion-making from a pretended outside' perspective is also indebted to Edward Said and subsequent post-colonial critics of academia's involvement in colonial politics of religionization. ${ }^{48}$ It is important to consider how scholarly religion-making is interrelated with the other discussed modes of religion-making, in particular with religion-making from above. Tomoko Masuzawa's The Invention of World Religions,$^{49}$ is an example of such a dual perspective, as are the contributions of other authors in the post-colonial tradition. ${ }^{50}$

I suggest reflecting on cultural encounters, and the translations and negotiations of new and old concepts and practices that they engender as an additional arena of religion-making. Studies on intercultural exchanges from early modern imperialism, and the concomitantly expanding missionary project, through to the age of colonialism have contributed greatly to our understanding of the dynamic character through which modern notions of religion and, consecutively, secularities have emerged globally. These notions are connected semantically but separated organizationally - though with manifold particularities according to various historical, political, and cultural factors. Reflection on the increasing entanglements of knowledge with regard to religion and secularities since the early modern period ${ }^{51}$ adds a historical dimension that can serve as a corrective to a too narrowly modern framework for religionization. Notions of encounter, translation, and entanglement also challenge overly static conceptual-

45 Smith, The meaning and end of religion.

46 Smith, "Religion, religions, religious."

47 For example McCutcheon, Manufacturing religion and McCutcheon, "The category 'religion."'

48 For a similar, though more elaborate, discussion of this discipline-critical trajectory within the study of religion, see Beyer, "Conceptions of religion."

49 Masuzawa, Invention of world religions.

50 Such as Chidester, Savage systems and Chidester, Empire of religion.

51 Van der Veer, Imperial encounters; Banchoff and Casanova, The Jesuits and globalization; Bentlage et al., Religious dynamics. 
izations of the particular locations from which religion-making is undertaken such as those defined in the three agency-centered modes of religion-making discussed above.

Notions of encounter and translation further provide a means to address comparable processes of discursive normalization roughly in parallel to the religionization politics that have so far been addressed. Bjørn Ola Tafjord has recently discussed the politics of 'scaling' and 'translation' in the practices through which the Bribris of Talamanca (Costa Rica) have been and continue to be indigenized, that is, thought about through the trope of indigeneity from within various missionary, political, and/or scholarly agendas. ${ }^{52}$ As he shows, this trope has been effectively appropriated by the Bribris themselves. 'Indigeneity' and 'religion' have in common that they were heavily used in charting pathways and terrains in which colonial, missionary, and local modernizing agents, as well as scholars, were able to place and control given social realities that at first sight fit awkwardly with dominant cartographies of knowledge and their classification systems:

Scholars with theoretical ambitions, who work with comparisons of multiple and often distant cases, and who rely on reports produced by others for their empirical data, seem especially liable to schematic classifications. The less they know about Talamanca and the broader the perspective of their scholarly undertaking, the more prone they are to place practices of Bribris in pre-established boxes like "animism," and "indigenous religion.". 53

While religion unsurprisingly plays a major role in the discursive indigenization from above and from the pretended outside that Tafjord describes, the Bribris themselves have mostly remained resistant to the suggestion that their cherished indigeneity ought to be connected to a particular type of 'religion.' That a minority of Bribris has begun to engage in religion-making of the 'from below' type discussed above is only a rather recent phenomenon:

Young, well-educated and politically engaged Bribris use academic conversations, literature, and categories as aids to analyse, translate, rearticulate and promote not just their own cultura in-

52 Tafjord, "Scales, translations, and siding effects."

53 Ibid., 161. 
dígena and tradiciones indigenas, but now also their own religion indígena: externally, for example in political and legal settings. ${ }^{54}$

The notion of religion-making has been meant as a heuristic device for inquiry into the continuing construction of concepts of religion, the secular, and their derivatives, as well as the social formations related to these concepts. Reflecting, by means of distinction between different modes of religion-making, on the various interests and corresponding knowledge arrangements that undergird the social construction of religion (and the secular) can be seen as one agency-focused mode of inquiry into mechanisms of religionization and religio-secularization. The purpose of distinguishing between modes of religion-making is analytical. It is a heuristic operation to render visible the complexities and interrelations between various interests behind religionization processes and the historical constellations that they reflect and respond to.

A few examples will suffice to provide an idea of the various ways in which different forces conjoin in the codification of religions. Within the context of the modern state, nation-building and politics of doxa are often closely interrelated. The religionization of Islam (discussed above) points to how nationalism (or, the reference problem of social or national integration) and correspondingly the struggle for orthodoxy and its social and political objectification within the framework of the nation-state (or, the reference problem of religious heterogeneity) have constituted particularly friendly arenas for integrated practices of religion-making. As Peter Beyer has remarked:

It is no accident that movements toward identification and orthodoxification among religions have so often correlated - without necessarily being identical - with the rise of movements that seek to form or control a modern state in the name of its indigenous, supposedly primordial, community. ${ }^{55}$

Kimberly Hart's anthropological study of the 'orthodoxification' of Islam in Western Anatolia can be read as an example of the vernacular adaptation of state-sponsored Sunnification politics. ${ }^{56}$ In my own work on the formation of the modern understanding of Turkish Alevism as a 'heterodox' Turkish Muslim formation, I have demonstrated the integration of nation-

54 Ibid., 169.

55 Beyer, "What counts as religion," 133.

56 Hart, And then we work for God. 
alist scholarship and state politics in the normalization of this knowledge, which was eventually adopted by the Alevis themselves. ${ }^{57}$

\section{Conclusion}

It has been argued in this article that in the modern context processes of religionization are intrinsically related to processes of secularization and that their mutual affirmation is reflected in the formation of secularities: distinctions and differentiations, through which both religion and the secular become recognizable and which therefore both reflect and contribute to a religio-secular episteme.

From the perspective of the Multiple Secularities project, the notions of religionization and religion-making highlight the historical and dynamic character of the formation of secularities against the background of changing discourses about religion, often triggered by specific reference problems. Informed mainly by social constructivism and post-colonial approaches, the notions of religionization and religion-making are meant to offer complementary angles on the epistemological, social, historical, and political factors that shape and influence (1) discursive distinctions between the religious and its various others/outsides, (2) social and organizational structures that differentiate religious from non-religious domains, and (3) the relationship between discursive, material, and structural dimensions in the formation of such distinctions and differentiations.

57 Dressler, Writing religion. 
Al-Azmeh, Aziz. Die Islamisierung des Islam: Imaginäre Welten einer politischen Theologie. Frankfurt: Campus Verlag, 1996.

Al-Raziq, 'Ali 'Abd. Al-Islām wa Ușūl al-Hukm. Kairo: Miṣp, 1925.

Al-Raziq, 'Ali 'Abd. "Message not government, religion not state." In Liberal Islam: A sourcebook. Edited by Charles Kurzman, 29-36. New York: Oxford University Press, 1998.

Asad, Talal. Genealogies of religion: Discipline and reasons of power in Christianity and Islam. Baltimore: Johns Hopkins University Press, 1993.

Asad, Talal. Formations of the secular: Christianity, Islam, modernity. Stanford: Stanford University Press, 2003.

Asad, Talal. "Responses." In Powers of the secular modern: Talal Asad and his interlocutors. Edited by David Scott and Charles Hirschkind, 206-41. Stanford: Stanford University Press, 2006.

Banchoff, Thomas F., and José Casanova, eds. The Jesuits and globalization: Historical legacies and contemporary challenges. Washington: Georgetown University Press, 2016.

Bauer, Thomas. Die Kultur der Ambiguität. Eine andere Geschichte des Islams. Berlin: Verl. der Weltreligionen, 2011.

Bentlage, Björn, Marion Eggert, Hans Martin Krämer, and Stefan Reichmuth, eds. Religious dynamics under the impact of imperialism and colonialism: A sourcebook. Leiden, Boston: Brill, 2016.

Beyer, Peter. "What counts as religion in global society? From practice to theory." In Religion in the process of globalization. Edited by Peter Beyer, 125-50. Würzburg: Ergon, 2001.

Beyer, Peter. "Conceptions of religion: On distinguishing scientific, theological, and 'official' meanings." Social
Compass 50, no. 2 (2003): 141-60.

Bourdieu, Pierre. "Genesis and structure of the religious field." Comparative Social Research 13 (1991): 1-44.

Boyarin, Daniel. Dying for God: Martyrdom and the making of Christianity and Judaism. Stanford: Stanford University Press, 1999.

Boyarin, Daniel. Border lines: The partition of Judaeo-Christianity. Philadelphia: University of Pennsylvania Press, 2004.

Chidester, David. Savage systems: Colonialism and comparative religion in southern Africa. Charlottesville: University Press of Virginia, 1996.

Chidester, David. Empire of religion: Imperialism and comparative religion. Chicago: University of Chicago Press, 2014.

Dressler, Markus. "Religio-secular metamorphoses: The re-making of Turkish Alevism." Journal of the American Academy of Religion 76, no. 2 (2008): 280-311.

Dressler, Markus. Writing religion: The making of Turkish Alevi Islam. New York: Oxford University Press, 2013.

Dressler, Markus. "Beyond religiosecularism: Toward a political critique." The Immanent Frame. February 25, 2014. https://tif.ssrc. org/2014/02/25/beyond-religiosecularism-toward-a-politicalcritique/.

Dressler, Markus. "The social construction of reality (1966) revisited: Epistemology and theorizing in the study of religion," Method \& Theory in the Study of Religion 2018: 1-32, doi: https://doi. org/10.1163/15700682-12341434.

Dressler, Markus, Monika Wohlrab-Sahr, and Armando Salvatore. "Islamicate secularities: New perspectives on a contested field of research." Historical Social Research, special issue, (2019), forthcoming.

Dressler, Markus, and Arvind-Pal S. Mandair, eds. Secularism and 
religion-making. New York: Oxford University Press, 2011.

Gazi, Faisal. "The first Muslim secularist." The Guardian. International Edition, April 9, 2009. https://www. theguardian.com/commentisfree/ belief/2009/apr/09/religion-islamsecularism-egypt.

Glei, Reinhold, and Stefan Reichmuth, "Religion between Last Judgement, law and faith. Koranic dīn and its rendering in Latin translations of the Koran." Religion 42, no. 2 (2012): 247-71.

Hart, Kimberly. And then we work for God: Rural Sunni Islam in western Turkey. Stanford: Stanford University Press, 2013.

Hoyland, Robert. The late antique world of early Islam: Muslims among Christians and Jews in the East Mediterranean. Princeton: The Darwin Press, 2015.

Hurd, Elizabeth Shakman. "Alevis under law: The politics of religious freedom in Turkey." Journal of Law and Religion 29, no. 3 (2014): 416-35.

Hurd, Elizabeth Shakman. Beyond religious freedom: The new global politics of religion. Princeton: Princeton University Press, 2015.

Izutsu, Toshihiko. God and man in the Koran: Semantics of the Koranic Weltanschauung. Kuala Lumpur: Islamic Book Trust, 2008.

Jansen, Yolande. "Beyond comparing secularisms. A critique of religiosecularism." In Oxford Handbook of Secularism. Edited by Phil Zuckerman and John R. Shook, 369-89. Oxford: Oxford University Press, 2017.

Kleine, Christoph, and Monika WohlrabSahr. „Research programme of the HCAS 'Multiple Secularities - Beyond the West, Beyond Modernities". Leipzig: 2016. www.multiplesecularities.de/media/multiple_ secularities_research_programme.pdf.

Mandair, Arvind-Pal S., and Markus Dressler. "Introduction: Modernity, religion-making, and the postsecular." In Secularism and religion-making.
Edited by Markus Dressler and Arvind-Pal S. Mandair, 3-36. New York: Oxford University Press, 2011.

Marty, Martin E. "Our religio-secular world." Daedalus 132, no. 3 (2003): 42-48.

Masuzawa, Tomoko. The invention of world religions: Or, how European universalism was preserved in the language of pluralism. Chicago: University of Chicago Press, 2005.

McCutcheon, Russell T. Manufacturing religion: The discourse on sui generis religion and the politics of nostalgia. New York: Oxford University Press, 1997.

McCutcheon, Russell T. “The category 'religion' in recent publications: Twenty years later." Numen 62 (2015): 119-41.

Mehmed Şevket, es-Seyyid Efendi. Eser-i Sevket tıpkıbasım. Edited by Yaşar Alparslan and Lütfi Alıcı. Kahramanmaraş: Noya Medya Kitaplığı, 2015.

Schulze, Reinhard. Der Koran und die Genealogie des Islam. Basel: Schwabe Verlag, 2015.

Smith, Jonathan Z. "Religion, religions, religious." In Critical terms for religious studies. Edited by Mark C. Taylor, 269-84. Chicago: University of Chicago Press, 1998.

Smith, Wilfred Cantwell. The meaning and end of religion. Minneapolis: Fortress Press, 1991.

Stack, Trevor. "Introduction." In Religion as a category of governance and sovereignty. Edited by Trevor Stack, Naomi R. Goldenberg and Timothy Fitzgerald, 1-20. Leiden: Brill, 2015.

Sullivan, Winnifred F., Robert A. Yelle, and Mateo Taussig-Rubbo, eds. After secular law. Stanford: Stanford University Press, 2011.

Tafjord, Bjørn Ola. "Scales, translations, and siding effects. Uses of 'indígena' and 'religión' in Talamanca and beyond." In Religious categories and the construction of the indigenous. Edited by Christopher Hartney and Daniel J. 
Tower, 138-77. Leiden: Brill, 2017.

Tayob, Abdulkader. Religion in modern

Islamic discourse. New York:

Columbia University Press, 2009.

Telle, Kari. "Faith on trial. Blasphemy and 'lawfare' in Indonesia." Ethnos 83, no. 2 (2017): 371-91.

Toven, Mehmet Bahaettin. Yeni Türkçe luğat. Edited by Abdülkadir Hayber. Ankara: Türk Dil Kurumu, 2015.

Van der Veer, Peter. Imperial encounters: Religion and modernity in India and Britain. Princeton: Princeton University Press, 2001.

Wohlrab-Sahr, Monika, and Marian Burchardt. „Multiple secularities: Toward a cultural sociology of secular modernities." Comparative Sociology 11, no. 6 (2012): 875-909. 




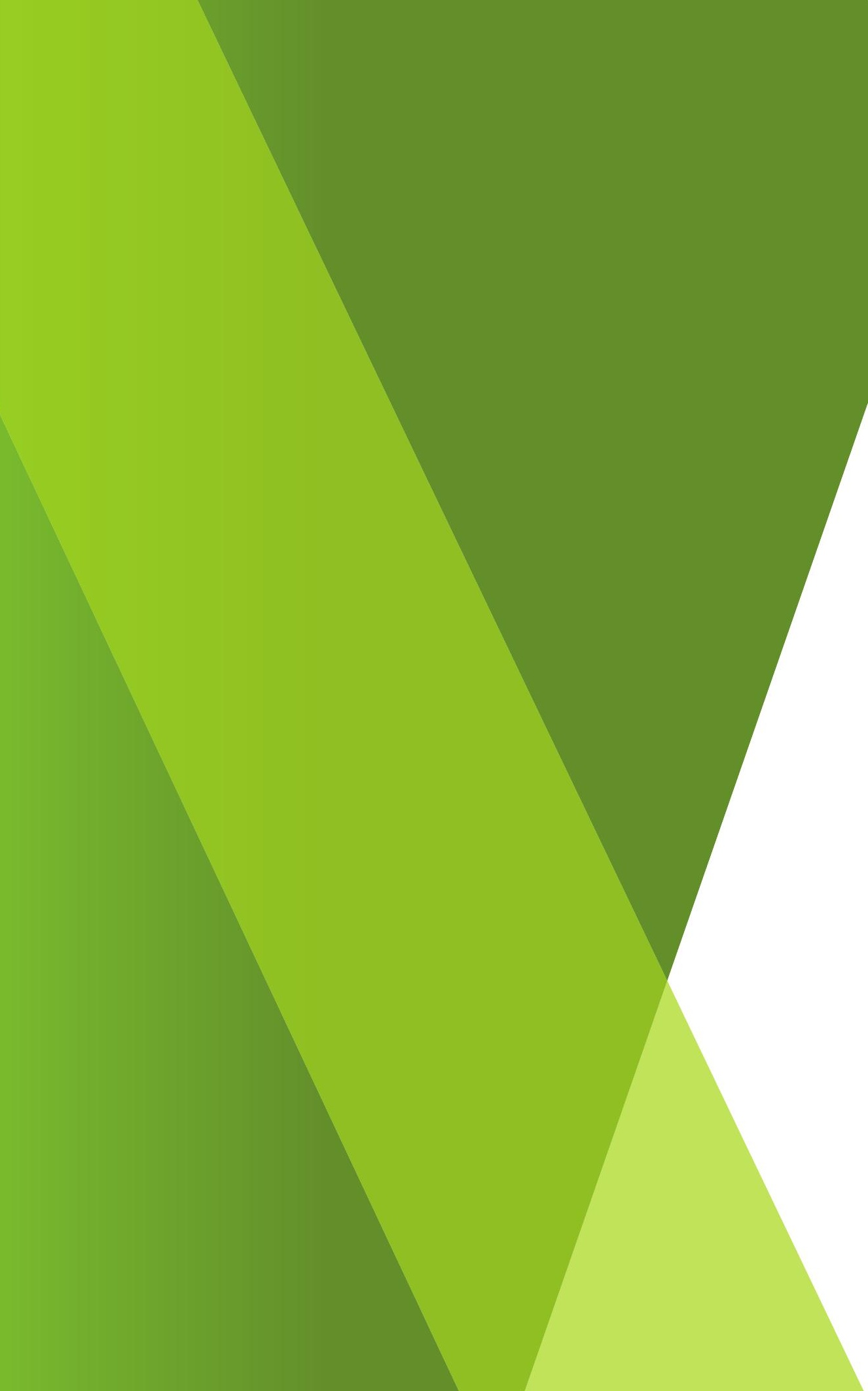

